\section{HISTORICAL} NEUROSCIENCE

\title{
Giovanni Aldini: From Animal Electricity to Human Brain Stimulation
}

\author{
André Parent
}

\begin{abstract}
Two hundred years ago, Giovanni Aldini published a highly influential book that reported experiments in which the principles of Luigi Galvani (animal electricity) and Alessandro Volta (bimetallic electricity) were used together for the first time. Aldini was born in Bologna in 1762 and graduated in physics at the University of his native town in 1782. As nephew and assistant of Galvani, he actively participated in a series of crucial experiments with frog's muscles that led to the idea that electricity was the long-sought vital force coursing from brain to muscles. Aldini became professor of experimental physics at the University of Bologna in 1798. He traveled extensively throughout Europe, spending much time defending the concept of his discreet uncle against the incessant attacks of Volta, who did not believe in animal electricity. Aldini used Volta's bimetallic pile to apply electric current to dismembered bodies of animals and humans; these spectacular galvanic reanimation experiments made a strong and enduring impression on his contemporaries. Aldini also treated patients with personality disorders and reported complete rehabilitation following transcranial administration of electric current. Aldini's work laid the ground for the development of various forms of electrotherapy that were heavily used later in the 19th century. Even today, deep brain stimulation, a procedure currently employed to relieve patients with motor or behavioral disorders, owes much to Aldini and galvanism. In recognition of his merits, Aldini was made a knight of the Iron Crown and a councillor of state at Milan, where he died in 1834.
\end{abstract}

RÉSUMÉ: Giovanni Aldini : de l'électricité animale à la stimulation cérébrale chez l'homme. Il y a exactement 200 ans, Giovanni Aldini publiait un ouvrage important dans lequel il résumait un vaste ensemble d'expériences effectuées en combinant pour la première fois le principe de Luigi Galvani (électricité animale) et celui d'Alessandro Volta (électricité bimétallique). Aldini naquit en avril 1762 à Bologne où il gradua en physique en 1782. En tant que neveu et assistant de Galvani, il participa activement aux travaux expérimentaux effectués chez la grenouille et qui conduisirent à l'idée que l'électricité est la véritable force vitale qui induit la contraction musculaire à partir des nerfs. Aldini occupa la chaire de physique expérimentale de l'Université de Bologne dès 1798. Il voyagea alors à travers l'Europe afin de défendre le concept d'électricité animale contre les attaques de Volta. Il utilisa la célèbre pile bimétallique de Volta afin d'administrer du courant électrique aux corps d'animaux à sang chaud et même à des cadavres d'humains suppliciés. Ces expériences spectaculaires de réanimation galvanique firent une forte impression sur ses contemporains. De plus, Aldini traita avec succès, semble-t-il, certains patients souffrant de troubles de l'humeur par stimulation électrique trans-crânienne. Ainsi, les travaux d'Aldini's conduisirent au développement de différentes formes d'électrothérapies utilisées intensivement au XIXe siècle. Même aujourd'hui, la stimulation cérébrale profonde, employée pour soulager certains patients souffrant de troubles moteurs ou comportementaux, doit beaucoup à Aldini et au galvanisme. En reconnaissance de sa contribution scientifique, Aldini fut fait Chevalier de l'Ordre de la Croix-de-Fer et nommé Conseiller d'état à Milan, où il mourut en janvier 1834.

Can. J. Neurol. Sci. 2004; 31: 576-584

Giovanni Aldini (Figure 1) was born in Bologna on the 16th of April, 1762 in a family that cherished culture in general and science in particular. His elder brother Antonio became an eminent jurist and worked actively for the unity of Italy. His mother, the sister of the famous Luigi Galvani (1737-1798), had a major influence on the orientation of her son towards science. ${ }^{1}$ Immediately after his graduation in physics from the University of Bologna on November 25, 1782, Aldini started to work as a research assistant in the humble laboratory that his uncle had set up at home. There, he joined Galvani's talented wife Lucia
Galeazzi (?-1791), Camillo Galvani (1765-1824), another nephew of Galvani who was already known for his work on the luminescent stone of Bologna, ${ }^{2}$ and a handful of Galvani's

From the Centre de Recherche Université Laval Robert-Giffard, Beauport, Québec, Canada.

Received January 9, 2004. AcCeptedin Finalform March 24, 2004. Reprint requests to: André Parent, Centre de Recherche Université Laval RobertGiffard, 2160, Chemin de la Canardière, Beauport, Quebec, Canada, G1J 2G3 


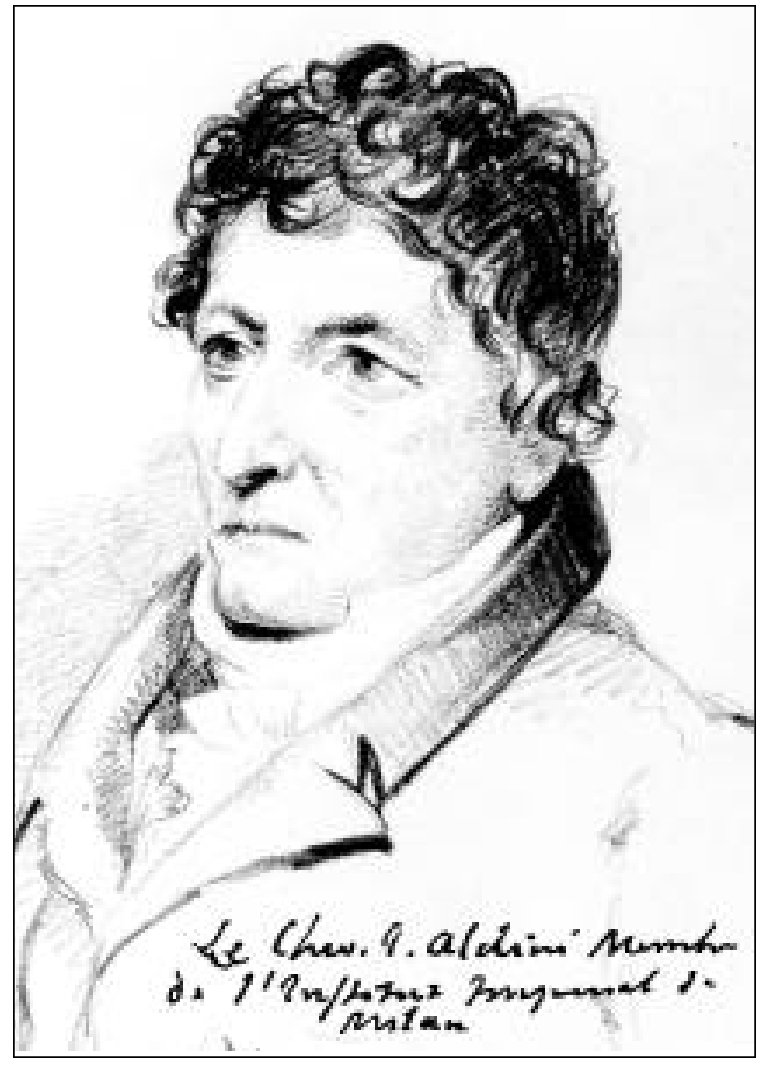

Figure 1: Giovanni Aldini at age 68. Chalk and pencil drawing by William Brockedon, London, 1830; courtesy of the National Portrait Gallery, London. Aldini's signature was taken from an inscription found on a copy of Aldini J. Art de se préserver de la flamme. Paris: Huzard, 1830. The inscription reads as follows: Le Chev. J. Aldini Membre de l'Institut Impérial de Milan (the chevalier J. Aldini member of the Imperial Institute of Milan). It was taken from the library of the Muséum National d'Histoire Naturelle, Paris, and electronically imported onto the portrait.

students. Together, they formed a small but very active scientific group that used various electricity-producing machines, such as primitive friction devices, condensers and Leyden jars in attempts to demonstrate the involvement of the electrical fluid (fluido elettrico) in muscle contraction in frogs. This work led to Galvani's famous essay entitled: De viribus electricitatis in motu musculari commentarius (Commentary on the Effects of Electricity on Muscular Motion) that was published in Bologna in $1791 .^{3}$ In his Commentary, Galvani describes the famous series of experiments that led him to realize that electric sparks can induce muscle contraction by triggering natural electricity within the nerves themselves. He proposed that the brain generates electricity that is distributed through the inner core of the nerves down to the muscles. The concept of intrinsic animal electricity proposed by Galvani in his Commentary has had a major impact on several scientists, including Leopoldino Nobili (1784-1835) and Carlo Matteucci (1811-1868), who eventually demonstrated the importance of the so-called lesion current in muscular contraction produced by the simple contacts of animal parts. $^{4,5}$ Galvani is thus at the origin of a major scientific trend that led to the development of modern electrophysiology. ${ }^{6-9}$

The capacity of certain animals to generate electricity was known and exploited in the healing arts since antiquity. For example, Scribonius Largus (fl. c. 14-54 AD) in ancient Rome used shocks produced by electric rays to treat a wide variety of illnesses, including headache, gout and different types of paralyses. ${ }^{10}$ The therapeutic use of electricity was facilitated by the advent of the Leyden jar - the first electricity storage device - in the middle of the 18th century. Later on, the famous Swiss physiologist Albrecht von Haller (1708-1777) insisted on the fact that various human body tissues, principally nerves and muscles, were sensitive to stimulation by electricity. ${ }^{11}$ Several scientists of this period agreed that nerve and muscles were made of highly excitable tissues but, in contrast to Galvani, they did not believe that electricity played a role in their normal functioning.

Also at odds with Galvani's concept of animal electricity is the notion of animal magnetism, advocated by the German physician Franz Anton Mesmer (1734-1815). Mesmer, whose medical dissertation dealt with the influence of the planets on the human body, believed that all living beings are interconnected by a universal magnetic force, a sort of fluid that had to flow harmoniously throughout the body to ensure health and strength. ${ }^{12}$ During the course of very popular public sessions that were held first in Vienna and later in Paris, Mesmer used magnets, electrodes and other devices to restore the flow of the magnetic fluid within the body of patients who suffered from disorders as varied as hysteria and blindness. However, the concept of animal magnetism or mesmerism did not survive the severe but lucid report of the commission of the French Academy of Sciences that was established in 1784 by Louis XVI to evaluate Mesmer's practice. The commission's report contains the following sentence that is quite revealing of the general tone of the document: "Animal magnetism may exist without being useful, but it cannot be useful if it does not exist." In contrast to the notion of animal electricity, the concept of animal magnetism did not contribute at all to the advancement of knowledge about neural transmission. In all fairness, however, it must be said that Mesmer's work led, through a large series of indirect links, to the development of hypnosis, which was used and abused by several neurologists at the end of the 19th century. ${ }^{13-15}$ To our knowledge, there is no evidence that Galvani or Aldini ever met with Mesmer, whose work was published well before that of the two Italian scientists. However, Aldini was well aware of Mesmer's contribution, which he regarded as pure charlatanism.

In 1791, most scientists received Galvani's results with great enthusiasm, including Alessandro Volta (1745-1827) from Pavia, who congratulated Galvani for his elegant series of experiments. However, Volta became rapidly critical about the way Galvani interpreted his results. He argued that, instead of demonstrating the existence of intrinsic animal electricity (elettricità animale), the muscle contractions observed by Galvani were the result of electricity generated by two dissimilar metals (elettricità metallica). Volta later used this concept to create his famous electric pile, for which he is still remembered today. Indeed, in many experiments performed by Galvani, the frog muscle preparations were hanging on a brass hook and muscle contractions were most easily elicited when the hook was deliberately pressed against an iron railing. Volta believed that 
Galvani had shown that electricity can be a powerful stimulus for nerves and muscles - a concept that was already accepted at that time - but did not prove that muscles contract because of electricity intrinsic to the body. ${ }^{16}$ A major fight between the School of Bologna and that of Pavia ensued and the whole issue remained unsettled until the beginning of the 20th century.

\section{The Aldini-Volta debate}

Galvani had a reserved character and confined life and he was reluctant to intervene directly in what became known as the Galvani-Volta controversy. ${ }^{17}$ This was not the case of his youthful and spirited nephew Aldini, who rapidly took over the defense of his uncle's idea and, in so doing, became the most ardent propagandist of the concept of animal electricity or, as he called it, galvanism. First, Aldini took charge of the second printing of Galvani's commentary that appeared in Modena in 1792 and to which he added several notes as well as an introductory 26-page assay that outlined his personal views on animal electricity. ${ }^{18}$ Second, he conducted further experiments, including some on warm blooded animals, whose results were arranged in two dissertations that were read before the Bologna Institute of Sciences and subsequently published as De animali electricitate dissertationes duae (Two dissertations on animal electricity). ${ }^{19}$ Third, Aldini helped his uncle in the preparation of an anonymous tract, the Trattato dell'arco conduttore (Treatise on the conducting arc) ${ }^{20}$ which appears to be Galvani's main response to Volta's criticisms. To this tract, Aldini added a 20page Supplemento in which he describes experiments that led to the production of muscle contractions without the use of metals of any kind, a finding that strongly supports the involvement of animal electricity in the working of the nervous system. ${ }^{21}$ Aldini was so active in defending galvanism that the work of his retiring uncle was, for some time, almost entirely forgotten. Volta had now to answer directly the arguments put forward by the energetic Aldini and what is known today as the famous GalvaniVolta controversy was, at that time, perceived as a debate between Aldini and Volta.

In the first of his two 1794 dissertations, Aldini alludes to Volta's attacks on galvanism as follows:

"This sort of revolution in Galvani's system came to my attention at the time he [Galvani, who was primarily a physician and an anatomist $]^{22}$ was treating me for a deadly fever. After having escaped, thanks to his generous care and efforts, a nearly unavoidable death, I started to work zealously to bring support to a doctrine that I trusted, despite the attacks under which it came. I felt at ease to be able to pay a tribute to the truth and, at the same time, to provide Galvani with a public account of my gratitude. ${ }^{19,23}$

Amongst Aldini's major contributions to galvanism is the demonstration that muscular contraction in frogs can be obtained with one metal only. Aldini used purified mercury as the sole link between the crural nerve and the leg muscles, and each time the three elements of this electric arc (nerve-mercury-muscle or muscle-mercury-nerve) were in contact, a muscular contraction occurred (Figure 2A). This experiment, first reported as a note in the second edition of Galvani's Commentary, ${ }^{24}$ was praised by the famous German scientist Alexander von Humboldt (17691859) who wrote:

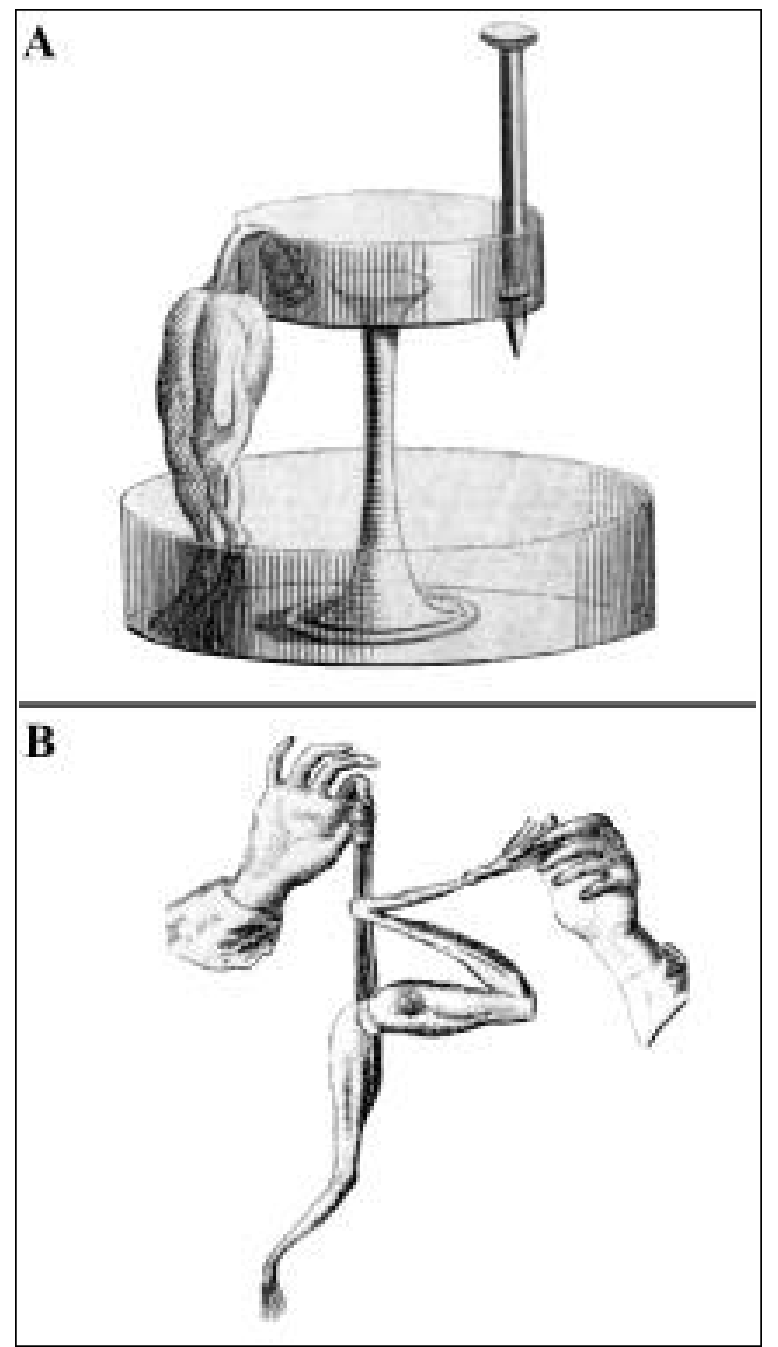

Figure 2: A: Drawing of one of the many devices that Aldini designed to demonstrate that frog muscle contractions occur even when only one metal, namely mercury, is used to convey galvanism. This particular apparatus is composed of two glass vessels placed one inside the other. The upper vessel is filled with mercury and receives the spinal cord of a prepared frog. A hole at its bottom allows the experimenter to let drops of mercury fall on frog muscles hanging in the lower vessel; each time this happens, a muscle contraction occurred. This figure was first published in Aldini's 1794 dissertations.

$B$ : Aldini's drawing of the famous experiments demonstrating that muscle contractions can be obtained without the use of any metals. Here, a muscular twitch is produced each time frog muscles are put in contact with crural nerves. This experiment was first described, but not illustrated, in the supplement to the anonymous Treatise on the Conducting Arc (Bologna, 1794). Both figures are reproduced from the author's own copy of Aldini J. Essai théorique et expérimental sur le galvanisme. Paris: Fournier Fils, 1804.

"Aldini in Bologna has opened a safer avenue; he reported his experiments with mercury and surpassed all his forerunners in the same field by the variety and fineness of his experiments, and by the ingenuity of his methodological approach. However, 


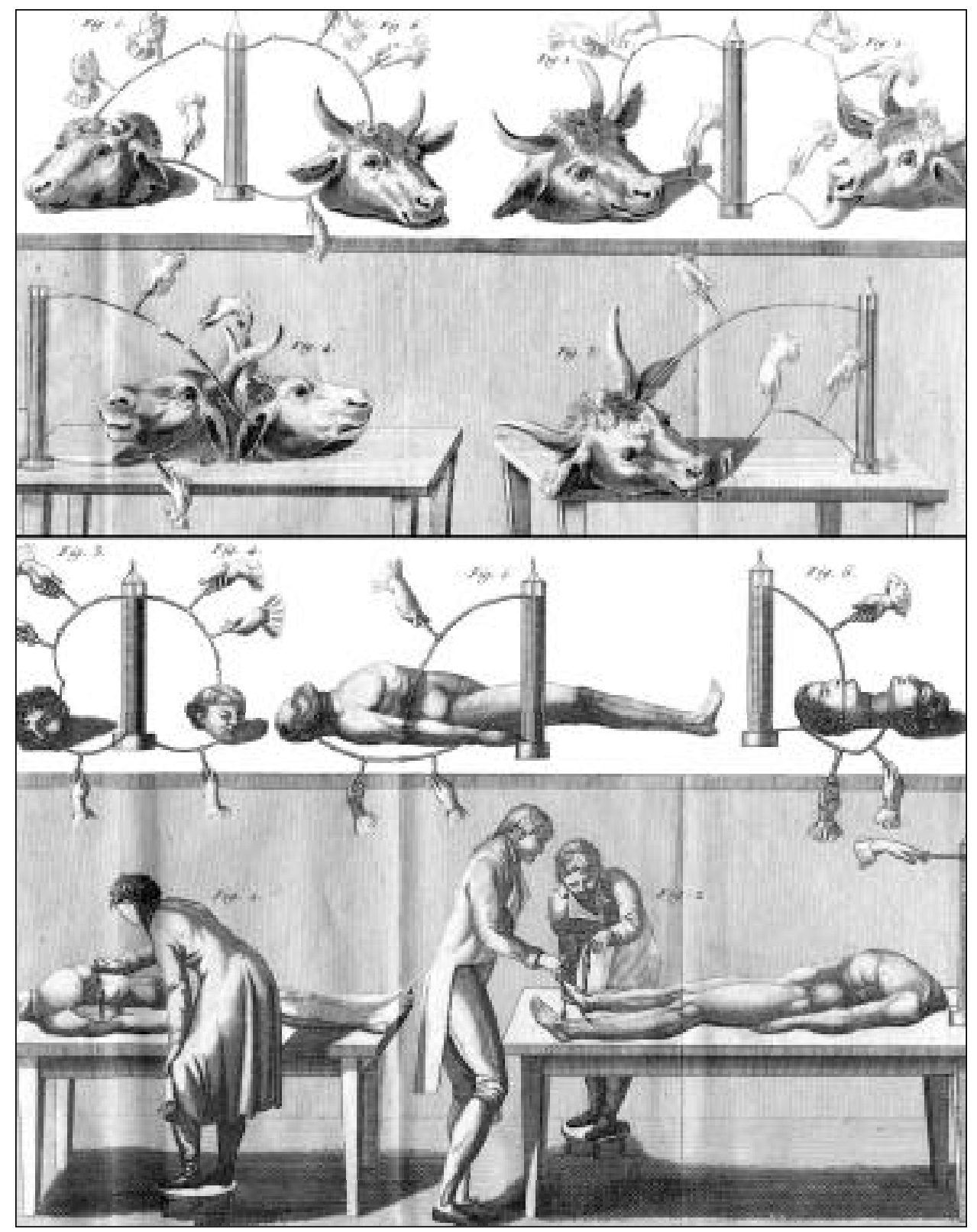

Figure 3: Reproductions of plate II (upper panel) and plate IV (lower panel) in Aldini J. Essai théorique et expérimental sur le galvanisme. Paris: Fournier Fils, 1804. These engravings, based on beautiful drawings by Pecheux, provide a stunning view of the various procedures that Aldini and his assistants used to electrify the bodies of various warm blooded animals, including lambs and oxen (upper panel), as well as corpses of criminals (lower panel) that were decapitated in Bologna in 1802. Aldini left no illustrations of the highly publicized experiments he did in London on the body of Gorge Foster.

because his results tended to overturn a generally accepted theory to which people were strongly attached, he met the same fate that awaits all scientists in such a case: the facts he reported were denied and he was accused of error. ${ }^{25}$

Indeed, Aldini was immediately blamed by Volta for having misinterpreted the results of his experiments. Sticking to his concept of bimetallic electricity, Volta argued that Aldini was successful in producing muscle contractions not because of the existence of inherent animal electricity but simply because the mercury he used was not sufficiently purified and contained traces of at least another metal. It is this type of reaction that convinced both Aldini and Galvani to initiate the series of experiments wherein no metals of any kind were used to induce muscular contraction (la contrazione sensa metallo); such a contraction was obtained simply by applying the cut-end of the crural nerve to the leg muscles. The results of this crucial experiment made the central theme of the Supplemento that was appended to the Treatise on the Conducting Arc, published 
anonymously in $1794 .{ }^{20}$ The treatise itself was reprinted only once - in Galvani's Opere published in $1841^{26}$ - but the supplement was reprinted three times and was translated into French and English. ${ }^{21}$ The treatise and its supplement did not contain any figures but Aldini illustrated some aspects of the famous experiment in his later works (Figure 2B). Aldini was also a major contributor to Galvani's Memorie sulla elettricità animale (Dissertation on animal electricity), ${ }^{27}$ which was published in 1797 in the form of a letter dedicated to Lazzaro Spallanzani (1729-1799), a strong supporter of Galvani's theory, in contrast to his fellow-citizen, Volta. This very last contribution of Galvani contains the description of a decisive experiment whereby muscle contraction was obtained in the two legs of a frog by the simple contact of its two crural nerves.

\section{GaLVANISMAS A THERAPEUTIC TOOL}

In 1798, the year of the death of his uncle, Aldini accepted the Bologna University chair in physics, which was left vacant by the retirement of his former master Sebastiano Canterzani (17341819). The teaching load inherent to such a position did not stop Aldini from pursuing very actively his work on galvanism. It was at this period that he founded the first Galvanic Society in Bologna to foster this science and initiated a series of experiments on various warm blooded animals, including birds, lambs, calves and oxen (Figure 3, upper panel). In one of these experiments, Aldini applied direct electric current to different parts of an ox brain, which was still in place in the head of the animal, to determine the relative sensitivity of different cerebral regions to galvanism. Aldini obtained positive effects from many brain regions, but the most vigorous motor responses were seen after stimulation of the corpus callosum and cerebellum. ${ }^{23}$

Aldini's extensive series of experiments on warm blooded animals led him to consider the possibility of using galvanism as a therapeutic tool and he started to apply electricity on human cadavers to validate this novel application of galvanism. Aldini himself shed some light on the deep and rather ambitious motivation behind this unusual type of experimentation by writing:

"Convey an energetic fluid to the seat of all sensations; distribute its force throughout the different parts of the nervous and muscular systems; produce, reanimate and, so to speak, control the vital forces: this is the object of my research, this is the advantage that I intend to collect from the theory of galvanism. The discovery of the pile of the famous professor Volta served me as a torchlight throughout a long series of experiments and multiplied works that yielded interesting results." 23

It is ironic that, in order to convince people of the usefulness of galvanism as a therapeutic tool, Aldini had to rely on a device (the bimetallic pile) that was designed by Volta, his most ferocious enemy, largely on the basis of knowledge that the latter gathered from Galvani's original experiments. It is indeed with the help of a voltaic pile consisting of 100 discs made of zinc and as many made of copper that Aldini, with the help of several physicians, proceed to apply galvanism to various parts of the bodies of three criminals who had been killed by decapitation in Bologna. These spectacular demonstrations took place in January and February of 1802 in a large public area located near
Bologna's Palace of Justice, where the criminals had been sacrificed about an hour earlier. Aldini was able to produce all sorts of muscular contractions by applying an electric arc at different points along the head and body of the cadavers (Figure 3 , lower panel), hence confirming the results obtained previously with frogs. He noticed that such effects persisted up to three hours after death. However, Aldini was somewhat disappointed to see that what he considered to be the most important of all muscles - the heart - did not respond to galvanism as well as voluntary muscles. With the help of a certain Dr. Mondini, who was apparently knowledgeable in the field of neuroanatomy, Aldini then proceeded to stimulate various regions of the human brain. As in oxen, he obtained massive facial muscle contractions after stimulating the human corpus callosum; an effect that he associated with an epileptic seizure. More interestingly, Aldini was able to specifically stimulate the cerebral cortex of one hemisphere and obtain facial muscle contractions on the side opposite to that of the stimulation..$^{23}$ Unfortunately, Aldini did not further exploit this finding, which remained largely ignored and had to be rediscovered by scientists such as Gustav Theodor Fritz (1838-1927) and Eduard Hitzig (1838-1907), who applied electrical microstimulation to the cerebral cortex of dogs late in the 19 th century. ${ }^{28}$

\section{Aldini's European tour}

Aldini then started to travel throughout Europe to convince the scientific community of the existence of animal electricity and to demonstrate the usefulness of galvanism in the field of medicine. In the fall of 1802, Aldini lectured and experimented before several groups of scientists in Paris, including the members of the Royal Academy of Sciences. At la Salpêtrière Hospital, he met with the famous psychiatrist Philippe Pinel (1745-1826), who was astonished to see the muscular contractions that resulted from Aldini's application of galvanism on an old woman who had just died from "putrid fever." Pinel was even more impressed when he learned that Aldini was successful in using galvanism to treat patients suffering from various mental disorders in Bologna.

Aldini's most detailed account of such a treatment concerns Luigi Lanzarini, a 27-year-old farmer suffering from melancholy madness (major depression), who had been committed to Santo Orsola Hospital, in Bologna, on May 17, 1801. To properly treat the patient, Aldini first applied galvanism to his own head and the effects were stunning; in Aldini's words:

"First, the fluid took over a large part of my brain, which felt a strong shock, a sort of jolt against the inner surface of my skull. The effect increased further as I moved the electric arcs from one ear to the other. I felt a strong head stroke and I became insomniac for several days. $" 23$

Aldini initiated Lanzarini's treatment by using a rather weak voltaic pile that contained only 15 metal disks, but the intensity of the stimulation was increased later during the treatment. Optimal effects were obtained when the patient was keeping his hand on the bottom of the pile, while the arc emerging from the top of the apparatus touched his shaved and humidified parietal bone (Figure 4A). The patient's mood progressively improved so that Lanzarini was apparently completely cured several weeks after the beginning of the treatment. Aldini hired Lanzarini as a 


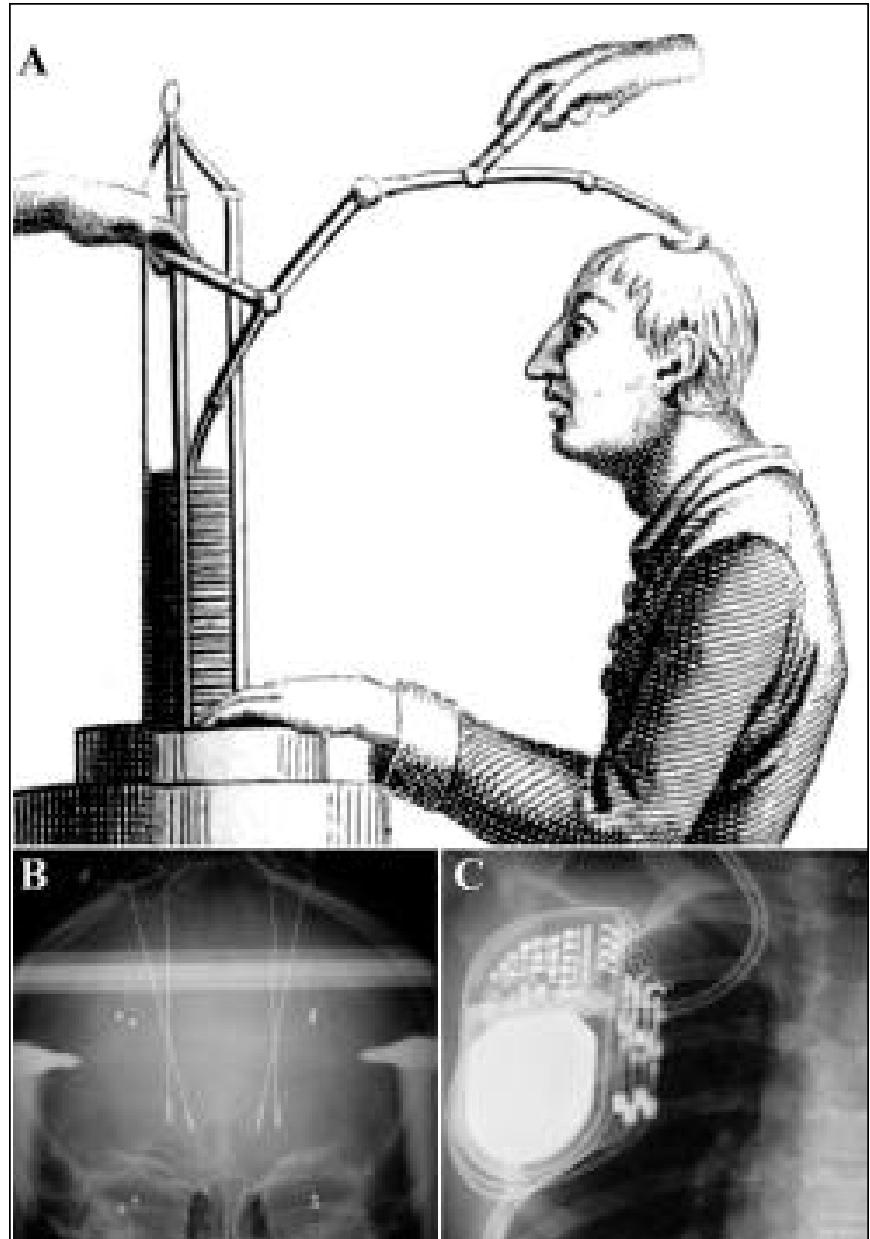

Figure 4: A: Details from plate $V$ in Aldini $J$. Essai théorique et expérimental sur le galvanisme. Paris: Fournier Fils, 1804. It illustrates Luigi Lanzarini to whom galvanism is being applied on the head. B, C: $X$-ray photographs showing stimulation electrodes implanted in the thalamus $(B)$ and the cor responding electrical stimulator located under the skin of the chest $(C)$ in a patient suffering from Parkinson's disease. Dr. A. L. Benabid, Université Joseph Fourier, Grenoble, France, kindly provided the X-ray photographs.

domestic staff at his home for a few days to be certain that he was now behaving normally and then let him rejoin his family in his natal village. ${ }^{23}$

Aldini also applied this primitive form of electroconvulsive therapy to some of the patients at la Salpêtrière, but with limited success. The major problem was that these patients were often agitated and displayed great terror in face of Aldini's unusual apparatus. Furthermore, most of them had their arms tied up so that they could not place their hands on the bottom of the voltaic pile. Nevertheless, Aldini was able to circumvent some of these limitations by applying the two ends of the electric arc on the ears, or even on the earrings of female patients. After Aldini left Paris, Pinel himself made several attempts to apply galvanism to some patients at la Salpêtrière, but he left no written accounts of these experiments.
At the beginning of 1803, Aldini came to England, where he lectured on medical galvanism in Oxford and London. He also gave practical lessons that consisted of applying galvanism to animal and human corpses, as he had previously done in Bologna. Many of these highly theatrical demonstrations were made in the anatomy amphitheatres of Guy's and St. Thomas Hospitals in London, before audiences composed of surgeons, physicians, gentlemen, dukes and even the Prince of Wales. ${ }^{29}$

Aldini's most famous demonstration took place on Monday, January 17, 1803, at the Royal College of Surgeons. There, Aldini used bimetallic electricity to shock and convulse the corpse of George Foster, a 26-year-old criminal who had just been hanged at the prison of Newgate for the murder of his wife and child who he had drowned in the Paddington Canal. It is worth noting that the Newgate Calendar specifies that Foster was executed on the 18th of January, 1803 (not on the 17th, as indicated in Aldini's writings), and stipulates that his "body be delivered to be anatomized." 30 The Newgate Calendar also mentioned: "After hanging the usual time, his [Foster's] body was cut down and conveyed to a house not far distant, where it was subjected to the galvanic process by Professor Aldini, under the inspection of Mr. Keate, Mr. Carpue and several other professional gentlemen." 30

Indeed, Aldini received the help of the anatomist and surgeon Joseph Constantine Carpue (1764-1846) for this demonstration. Dr. Thomas Keate (1745-1821), then President of the Royal College of Surgeons of London, directly supervised the entire galvanic session. Aldini specified that: "Galvanism was communicated by means of three troughs combined together, each of which contained forty plates of zinc, and as many of copper." The results were dramatic: when the rods were applied to Foster's mouth and ear, Aldini mentioned that "the jaw began to quiver, the adjoining muscles were horribly contorted, and the left eye actually opened." When one rod was moved to touch the rectum, the whole body convulsed: indeed, the movements were "so much increased as almost to give an appearance of reanimation."23,31,32 Aldini's demonstration was reported in detail in the London newspaper The Times (22 January 1803) and made a strong and enduring impression on the mind of scientists and ordinary people alike; many began to believe that electricity might be the long-sought vital force. Much of the state of mind of laypersons at that time is faithfully rendered in the novel Frankenstein, or the Modern Prometheus that the young Mary Wollstonecraft Shelley (1797-1851) published in 1818; the book rapidly became a classic in the field of gothic horror literature. ${ }^{33}$

Since that time, Aldini has often been considered as a sort of Dr. Faust, searching for a way to command the forces that govern human life. ${ }^{29}$ In fact, Aldini was pursuing a much more humble goal, which was to demonstrate that galvanism might be a useful tool in various reanimation procedures, principally those applied to individuals that suffered from asphyxiation by drowning. This was also a major concern for the Royal Humane Society, who sponsored Aldini's stay in London at that time. Aldini considered George Foster a typical case of asphyxiation and had this confirmed by the autopsy made on the cadaver, after the galvanic session, by Dr. Carpue and a medical student by the name of Hutchins. ${ }^{23,31,32}$ His highly publicized experiments on the London criminal were, in fact, a means for Aldini to complete the work he undertook in Bologna a few years earlier. There he had 
worked on animals in a state of near asphyxiation by drowning, but he was unfortunately unable to verify the efficacy of galvanism on humans under similar conditions, because the criminals he experimented upon had been killed by decapitation. The following excerpt is particularly revealing of Aldini's state of mind at that time:

"I think that this account will easily convince the readers that the experiments I did on the hanged criminal did not aim at reanimating the cadaver, but only to acquire a practical knowledge as to whether galvanism can be used as an auxiliary, and up to which it can override other means of reanimating a man under such circumstances. [...] I only wanted to recommend galvanism as the most powerful means to assist and augment the efficacy of all other stimulants." 23

\section{Aldini's Essay on GalvanisM}

Aldini provided a description in both English and French of his experiments on George Foster, as well as other demonstrations he made in England and France. The two accounts were published in 1803, one in London (an account of the late improvements in galvanism) $)^{31}$ and the other in Paris (Précis des expériences galvaniques faites récemment à Londres et à Calais). ${ }^{32}$ Hence, besides Italian, Aldini appears to have been fluent in both English and French; there is no mention of any translator involved in most of the work he published in these two languages. Accordingly, his first name varies in the different publications: he is referred to as Joannis Aldini in his early Latin dissertations, then as Jean or John Aldini in his French or English contributions and, of course, as Giovanni Aldini in all of his Italian publications.

Aldini's 1803 accounts were expanded to a sumptuous inquarto book containing more detailed descriptions of previous publications as well as declarations from investigators on both sides of the Channel. This two-volume, 680-page-long treatise entitled: Essai théorique et experimental sur le galvanisme was published in Paris in $1804,{ }^{23}$ that is, exactly 200 years ago. It is superbly well-written and contains 10 beautiful and highly informative plates drawn by Pecheux that vividly illustrate the various experiments made by Aldini during the last decade of the 18th century (Figure 3). The book is dedicated to Napoleon Bonaparte (1769-1821), who defeated the Austrian army in Northern Italy in 1796, and created there the Cisalpine Republic in 1797, of which the duchy of Milan and the legation of Bologna were part. The dedication reads as follows:

"It will be forever remembered in the splendor of the History of Galvanism the day when, just arriving in Italy, you allowed me to develop in front of you its main experiences, despite the vast military and politic activities that surrounded you. The memory of this honorable epoch emboldens me to dedicate this work to you. The support that you grant to all sciences also goes toward the progress of Galvanism: the monuments that you erected to its glory are great and worthy of your name. This homage is the expression of a public reconnaissance and a tribute that I render to the memory of Galvani, whose discovery, magnified by your auspices, will go, with your name, into immortality." 23

This text is ambiguous, to say the least, as it praises two figures that could not be more antagonistic: the proud and quarrelsome Napoleon and the humble and peaceful Galvani, the

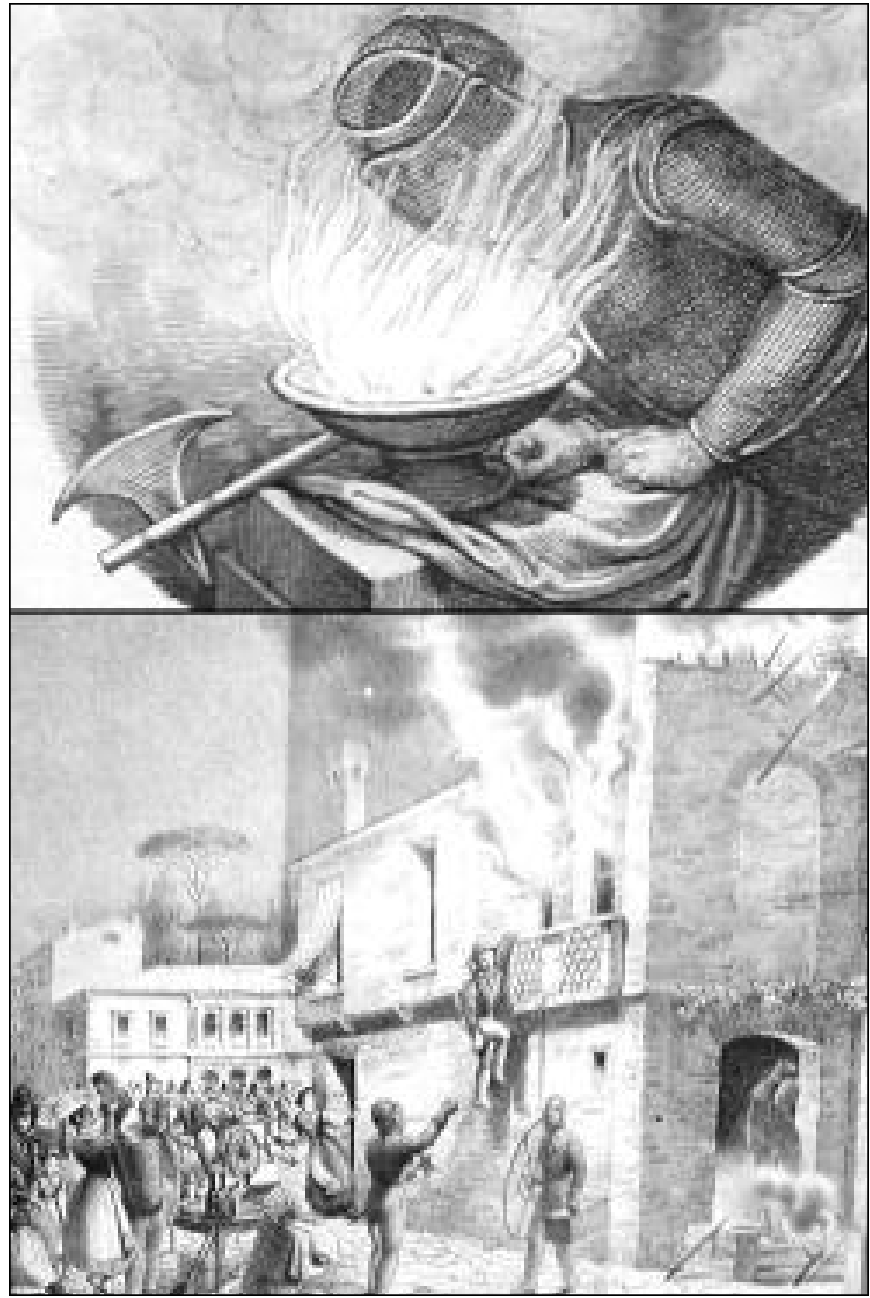

Figure 5: Details of some engraving made from drawings by Benoit Lemoine which appeared in Aldini J. Art de se preserver de la flame. Paris: Huzard, 1830. Upper panel: A fireman wearing an asbestos-made outfit and a mask that were specially designed to protect him from the fire. Lower panel: A lively scene showing firemen attempting to protect individuals and their goods against fire.

former having indirectly caused the loss of the latter. Indeed, because Galvani refused to take a civil oath to the new Napoleonic republic for political and religious reasons, he was dismissed from his University position, losing both his home and salary. He was forced to seek refuge in the house of his brother, where he died, cut off from science. ${ }^{8,21,22}$ We can assume that, in contrast to Galvani, Aldini accepted to pay allegiance to the Cisalpine republic, because he retained his University position in Bologna until he moved to Milan in 1807. This event underlines a major character difference between Aldini and Galvani. The latter was a man of the old regime who could not accept the revolutionary and republican values promoted by the French Cisapline republic, whereas the former was a young and carefree person already fully embarked in the 19th century, which saw the 
birth of most of the major neuroscience concepts of today. From that point of view, Aldini appears closer to Volta than to Galvani: both Aldini and Volta accepted to take a civil oath to the Napoleonic republic and became, later in their careers, public administrators under the new regime.

In any event, Aldini's Essai théorique et experimental sur le galvanisme has had a considerable impact on scientists and laypersons interested in the basic issue of animal electricity as well as in the medical application of galvanism. Although Aldini's experiments might seem simplistic by current standards, they nevertheless inspired many of the various electrotherapies that are still in use today, such as cardiac electrical stimulation in cases of heart failure and electroconvulsive therapy for drugresistant depression. Aldini and his successors are also not far away when one considers deep brain stimulation, a new and sophisticated procedure that involves the administration of high frequency electric currents to silence specific subcortical brain structures, such as the subthalamic nucleus, ${ }^{13-15}$ which is overactive in various psychiatric and neurodegenerative diseases. In this procedure, which has shown its remarkable efficacy in Parkinson's disease, ${ }^{34}$ Aldini's apparatus has been conveniently replaced by an electric stimulator implanted in the chest of the patient who can turn it on and off at will (Fig. 4B,C).

\section{ALDINI's LAST PERIOD}

Aldini devoted the last part of his career to scientific matters more closely related to the world of physics than to that of medicine or biology. He first tried to improve the construction and illumination of lighthouses. ${ }^{35} \mathrm{He}$ then spent considerable amounts of time designing new means, including the use of asbestos fibers, to improve firefighting and to protect individuals and their goods against fire. This part of his activities is summarized in a beautifully illustrated book entitled: Art de se préserver de l'action de la flame, published in Paris in 1830 (Figure 5). ${ }^{36}$ Aldini also developed novel hydraulic lever systems, made interesting observations on the flood tide, developed new means to ameliorate the use of water vapor in silk-weaving factories, ${ }^{37}$ and invented novel procedures to improve the lighting of streets and various buildings, including Milan's famous opera building, La Scala. ${ }^{38}$ These late contributions are congruent with his previous works in the field of galvanism; they underline Aldini's desire to improve the wellbeing of his fellow citizens.

In recognition of his scientific contribution, Aldini was made a knight of the Napoleonic Order of the Iron Crown (currently the Order of the Iron Crown of Austria) and, in 1807, a councilor of the state of Milan. Aldini thus abandoned his chair in physics at the University of Bologna and moved to the state capital of Lombardy, where he became superintendent of Milan's main library and set up an impressive science cabinet typical of that period. ${ }^{1}$ Aldini died on the 17 th of January 1834 in Milan at the age of 72 . He left by will a considerable sum to found a school of physics and chemistry for the artisans of Bologna; he also bequeathed all his manuscripts, as well as those of Galvani that he had at hand, to the scientific library of his native town.

Aldini devoted a large part of his life to galvanism. He first participated actively in Galvani's experiments designed to demonstrate the existence of animal electricity; he then traveled throughout Europe to defend and popularize this concept and convince the scientific community of the usefulness of galvanism in the field of medicine. Aldini was thus a key player in a battle that led to a major neuroscience paradigm shift, ${ }^{39}$ that is, the transition from the 1500-year-old galenic concept of animal spirits, which were thought to be stored into the brain ventricles and coursed within the hollow nerves to induce muscular contraction, to that of animal electricity.

\section{ACKNOWLEDGEMENTS}

The author thanks Martin Parent, Centre de Recherche Université Laval Robert-Giffard, Quebec, for his help with the illustrations and Dr. Alim Louis Benabid, Université Joseph Fourier, Grenoble, France, for having provided the X-ray photographs reproduced in Figure 4. Thanks are also due to Mrs. B. Molitor and M. Ducreux, for giving me access to the rare book section at their respective libraries: the Bibliothèque Interuniversitaire de Médecine and the Bibliothèque Centrale du Muséum National d'Histoire Naturelle in Paris.

\section{REFERENCES}

1. Scarpelli G. Aldini, Giovanni: a Biography. KOS 1984; 2: 25-27.

2. Galvani C. Della pietra fosforica Bolognese. Bologna: Longhi, 1780

3. Galvani L. De viribus electricitatis in motu musculari commentarius. De Bononiensi Scientiarum et Artium Instituto atque Academia Commentarii 1791; 7: 363-418.

4. Nobili L. Comparaison entre les deux galvanomètres les plus sensibles, la grenouille et le multiplicateur à deux aiguilles, suivi de quelques résultats nouveaux. Ann Chim Phys 1828; 38: 225245.

5. Matteucci C. Deuxième mémoire sur le courant électrique propre de la grenouille et sur celui des animaux à sang chaud. Ann Chim Phys 1842; 6 (série 3): 301-339.

6. Hoff HE. Galvani and the pre-galvanian electrophysiologists. Ann Sci 1936; 1: 157-172.

7. Pupilli CG, Fadiga E. The origin of electrophysiology. Journal of World History 1963; 7: 547-589.

8. Finger S. Origins of Neuroscience. New York: Oxford University Press, 1994.

9. Piccolino M. Animal electricity and the birth of electrophysiology: the legacy of Luigi Galvani. Brain Res Bull 1998; 46: 381-407.

10. Sribonius Largus. Compositiones medicae. Joannes Rhodius recensuit, notis illustrauit, lexicon scriboniaum adiecit. Patavii, P. Frambotti, 1655

11. von Haller, A. Mémoire sur les parties sensibles et irritables du corps humain. Lausanne: Sigismon d'Arnay, 1760.

12. Mesmer FA. Mémoire sur la découverte du magnétisme animal. Geneva: Fr. Didot, 1784.

13. Parent A. Jules Bernard Luys and the subthalamic nucleus. Mov Disord 2002; 17: 181-185.

14. Parent A, Parent M, Leroux-Hugon V. Jules Bernard Luys: A singular figure of 19th century neurology. Can J Neurol Sci 2002; 29: 282-288.

15. Parent A. Auguste Forel: on ants and neurology. Can J Neurol Sci 2003; 30: 284-291.

16. Volta A. Account of some discoveries made by Mr. Galvani from Mr. Alexander Volta to Mr. Tiberius Cavallo. Phil Trans Roy Soc 1793; 83: 10-44.

17. Pera M. La rana ambigua: la controversia sull'elettricità animale tra Galvani e Volta. Torino: Giolio Einaudi, 1986. [English trans. by Mandelbaum J. The Ambiguous Frog: the Galvani-Volta Controversy on Animal Electricity. Princeton, NJ: Princeton University Press, 1992.]

18. Galvani L. De viribus electricitatis in motu musculari commentaries cum Joannis Aldini dissertatione et notis. Mutinae: Apud Societatem Typographicam, 1792.

19. Aldini J. De animali electricitate dissertationes duae. Bononiae: typ Instituti Scientiarum, 1794. 
20. Galvani L. Dell'uso e dell'attività dell'arco conduttore nelle contractioni dei muscoli. Bologna: a S. Tommaso d'Aquino, 1794.

21. Dibner B. Galvani-Volta; a controversy that led to the discovery of useful electricity. Norwalk, CT: Burndy Library, 1952.

22. Bresadola M. Medicine and science in the life of Luigi Galvani (1737-1798). Brain Res Bull 1998; 46: 367-380,

23. Aldini J. Essai théorique et expérimental sur le galvanisme, avec une série d'expériences faites devant des commissaires de l'Institut national de France, et en divers amphithéâtres anatomiques de Londres. Paris: Fournier Fils, 1804.

24. Fulton JF, Cushing H. A bibliographical study of the Galvani and the Aldini writings on animal electricity. Ann Sci 1936; 1: 239-268.

25. von Humboldt A. Versüche über die gereizte Müskel- und Nevernfaser, nebst Vermuthungen über den chemischen Process des Leben in der Thier- und Pflanzenwelt. 2 vols. Posen: Decker; Berlin: H. A. Rottmann, 1797. [French trans. by Jadelot J.-F.-N. Expériences sur le galvanisme et en general sur l'irritation des fibres musculaires et nerveuses. Paris: Imprimerie Didot Jeune, 1799.]

26. Galvani L. Opere edite ed inedited dall'professore Luigi Galvani raccolte e publicate per cura dell'Academia delle Scienze dell'Instituto di Bologna. Bologna: Dall'Olmo, 1841.

27. Galvani L. Memorie sulla elettricità animale al celebre Abate Lazzaro Spallanzani. Aggiunte alcune elettriche esperienze di Gio. Aldini. Bologna: Sassi, 1797.

28. Fritsch G, Hitzig E. Über die elektrische Erregbarkeit des Grosshirns. Archiv Anat Physiol wissenschaftl Med 1870; 37: 300-332.

29. Sleigh C. Life, death and galvanism. Stud Hist Biol Biomed Sci 1998; 29: 219-248.

30. The Complete Newgate Calendar. 1926. London: Navarre Society Ltd.
31. Aldini J. An account of the late improvements in galvanism, with a series of curious and interesting experiments performed before the commissioners of the French National Institute, and repeated lately in the anatomical theatres of London, to which is added an appendix containing experiments on the body of a malefactor executed at Newgate, and dissertations on animal electricity, 1793 and 1794. London: Cuthell \& Martin and J. Murray, 1803.

32. Aldini J. Précis des expériences galvaniques faites récemment à Londres et à Calais par Jean Aldini [...], suivi d'un extrait d'autres expériences, détaillées dans un ouvrage du même auteur, et qui ont été publiées à Londres par M. Nicholson. Paris: Levrault et Barrau, 1803

33. Shelley M. Frankenstein, or the Modern Prometheus. London: Lackington, Hughes, Harding, Mavor and Jones, 1818.

34. Benabid AL. Deep brain stimulation for Parkinson's disease. Curr Opin Neurobiol 2003; 13: 696-706.

35. Aldini G. Saggio di osservazioni sui mezzi atti a migliorare la costruzione e l'illuminazione dei fari. Milano: Societa tipographica classici Italiani, 1823.

36. Aldini J. Art de se préserver de la flamme, appliqué aux pompiers et à la conservation des personnes exposées au feu; avec une série d'expériences faites en Italie, à Genève et à Paris par M. le Chevalier Aldini. Paris: Huzard, 1830.

37. Aldini J. Recherche expérimentales sur l'application extérieure de la vapeur pour échauffer l'eau dans la filature de la soie. Paris: Huzard, 1819.

38. Aldini G. Memoria sulla illuminazione a gas dei teatri, e progetto di applicarla all I. R. Teatro della Scala in Milano. Milano: Societa tipographica classici Italiani, 1820.

39. Clower WT. The transition from animal spirits to animal electricity: a neuroscience paradigm shift. J Hist Neurosci 1998; 7: 201-218. 